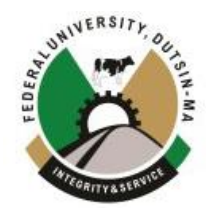

\title{
ESTIMATION OF CROP WATER REQUIREMENT AND CROP COEFFICIENT OF TOMATO CROP USING METEOROLOGICAL DATA IN PAMPAIDA MILLENNIUM VILLAGE, KADUNA STATE, NIGERIA
}

\author{
${ }^{1}$ A. Ahmed, ${ }^{2}$ M. A. Oyebode, ${ }^{2}$ H. E Igbadun and ${ }^{3}$ Oiganji Ezekiel \\ ${ }^{1}$ Bauchi State College of Agriculture, Bauchi, Nigeria \\ ${ }^{2}$ Department of Agricultural Engineering, Ahmadu Bello University \\ ${ }^{3}$ Department of Crop production, University of Jos, Nigeria \\ *Corresponding Author's Email: ahmedhabu@ gmail.com +2348023146832
}

\begin{abstract}
This report presents a study of crop water requirement and crop coefficient $(\mathrm{Kc})$ for Tomato crop cultivated under irrigation in Pampaida Millennium Village Cluster, Ikara Local Government Area of Kaduna State, Nigeria, during the 2009/2010 dry season. A total of 7 tomato farmers were selected out of 45 farmers for the assessment exercise. Water applied per irrigation and soil moisture contents before and after irrigation was monitored throughout the seasons, while Tomato bulbs were harvested at the end of season and weighed. Average crop water use were estimated from the soil moisture content using the gypsum block, while daily reference Evapotranspiration (ETo) were computed from weather data using method Hargreaves equation. Crop coefficient values $(\mathrm{Kc})$ were computed as the ratio of crop water use to ETo. The values of crop coefficients and seasonal crop water requirement per irrigation for different growth stages were determined, the computed $* \mathrm{~K}_{\mathrm{c}}$ values for different growth stage for the tomato crop grown in the study area was found to be between $0.77-1.15$, the initial stage $\left({ }^{*} \mathrm{~K}_{\mathrm{c}}=0.81 ; 20 \mathrm{~mm} /\right.$ irrigation $)$, crop development stage $\left({ }^{*} \mathrm{~K}_{\mathrm{c}}=1.09 ; 28\right.$ $\mathrm{mm} /$ irrigation $)$, mid-season $\left({ }^{*} \mathrm{~K}_{\mathrm{c}}=1.15 ; 29 \mathrm{~mm} /\right.$ irrigation) and Late stage $\left({ }^{*} \mathrm{~K}_{\mathrm{c}}=0.77 ; 19 \mathrm{~mm} /\right.$ irrigation$)$, hence the mid-season gave the highest Kc value. However, the crop seasonal water requirement was found to be $386 \mathrm{~mm}$, which was within the recommended range. The crop coefficients and seasonal water requirement estimated in this study are reliable and could be used in irrigation design and scheduling for Tomato in the study area.
\end{abstract}

Keywords: Evapotranspiration, growth stages, irrigation water, moisture content.

\section{INTRODUCTION}

The declining water resources and growing competition for fresh water has continued to reduce its availability for irrigation in arid and semi-arid regions. Feeding a planet of 8 billion by 2030 will require producing more food with less water and through improved water efficiency in Agriculture (World Bank, 2011).

Water plays a crucial role in determining the yield of tomato. To achieve better control and management of water in tomato production, the irrigation schedule should be based on the crop requirement for water. The optimum use of irrigation water is a fundamental stride in attaining sustainable Agriculture. Optimal level use of irrigation water for a particular situation is that which produces the maximum profit per unit of water applied (Ali, 2010).

Among others a key parameter commonly required in determining crop water requirement and prediction of yield water response to deficit irrigation is crop coefficient $(\mathrm{Kc})$. The $\mathrm{Kc}$ of a crop integrates crop and soil conditions that make a given crop's evapotranspiration more or less than the reference Evapotranspiration, furthermore, Kc are required as input data in some empirical water production functions. Crop coefficiency $(\mathrm{Kc})$ is the ratio of crop actual evapotranspiration (ETc) to a reference evapotranspiration (ETo) which can be calculated using the FAO-Penman-Monteith method (Igbadun and Oiganji, 2012).
Tomato (Lycopersicon esculentum Mill) is an important vegetable crop grown worldwide for both fresh and processing markets (Opiyo and Ying, 2005). In terms of acreage, it is the largest vegetable crop grown worldwide (Ho, 1996). The fruit is cultivated where climatic conditions are favourable and the seasonal water requirement is $300-600 \mathrm{~mm}$ (Schwah et al., 1993).

The Pampaida Millennium Village (PMV) comprises of 28 settlements with a population

of about 5,666 people .The community is a cluster of agrarian settlements that depend on rain fed agriculture as well as on smallholder traditional irrigation farming for their livelihood. Their livelihoods are mainly based on small-scale agriculture giving the region a characteristic presence of agricultural crops, trees and livestock (Ahmed, 2016).

In Pampaida Millennium Village, Kaduna, tomato is among the horticultural crops of high economic values. It is one of the major ingredient for making stews and soups which are eaten in virtually every home in once or twice a day (Igbadun and Oiganji, 2012). It is actually grown two times under dry season irrigation farming. However, in recent times, dry season farming in Pampaida is becoming increasingly difficult due to fluctuating weather conditions. This makes it difficult for the farmers to plan their irrigation schedules effectively and 
successfully (Sanchez et al., 2009).

The research gap in tomato production in the study location is the knowledge of water requirement for tomato crop under irrigation using meteorological data. Hence, the objectives of this study were to develop crop coefficients for field-grown tomato under irrigation and to estimate crop water requirement for tomato for the study location. It is anticipated that the information generated in this study will be useful for the overall improvement of irrigation water management in the study area.

\section{MATERIALS AND METHOD}

The study was carried out in Pampaida Millennium Village (PMV) site located at Saulawa District in Ikara Local Government Area of Kaduna State,during 2009/2010 dry season farming.The PMV site is about $60 \mathrm{~km}$ from Zaria city of Kaduna State. The topography of the area is of gentle slopes gradually sloping downwards into a river. The general relief of the area could be described as a valley with good surface drainage for the non-flooded areas. During the rainy season, the low land areas get flooded creating a low lying seasonally flooded areas (fadama). A survey using a GPS shows that the Pampaida MV is located on latitude $11^{0} 29^{\prime} \mathrm{N}$ and longitude $8^{0} 15$ "E. The irrigated area covers about 120 ha. The irrigation method practiced at this site is mainly furrow irrigation with furrow lengths of between 3 to 10m. (Sanchez et. al., 2009).

Soil samples were taken from all the selected farmers' field at an incremental depth of $150 \mathrm{~mm}$ from the soil surface to a depth of $600 \mathrm{~mm}(0-15 \mathrm{~cm}, 15-30 \mathrm{~cm}, 30-45 \mathrm{~cm}$, and $45-60$ $\mathrm{cm})$. The samples were taken to the laboratory for the determination of field capacity and wilting point using pressure membrane apparatus at 0.3 atm and 15 atm respectively as reported by Michael, (1978). The textural analysis used was sieve hydrometer methods using standard procedures as described by Loveday, (1974).

\section{Reference crop Evapotranspiration}

An average of 10-year weather data was used, to determine the reference crop Evapotranspiration (ETo) using the Hargreaves equation (Equation1). Metrological data were collected from the Institute of Agricultural Research Samaru Zaria. The data collected was for 2008/2009 irrigation cropping season. The parameters collected were: Maximum and minimum temperature, Relative humidity, Wind speed, Sunshine hours, Solar Radiation, and average weekly Evapotranspiration for ten years from 1999-2009 using Hargreaves equation. The data were processed and used in the weekly estimation of Evapotranspiration using method Hargreaves equation.

$\mathrm{ET}_{\mathrm{o}}=0.0023\left(\mathrm{~T}_{\text {mean }}+17.8\right)\left(\mathrm{T}_{\max }-\mathrm{T}_{\min }\right)^{0.5} \mathrm{Ra}$

$\mathrm{ET}_{\mathrm{o}}$ is Reference crop Evapotranspiration ( $\mathrm{mm} /$ day),

$\mathrm{T}$ mean is mean daily temperature $\left({ }^{\circ} \mathrm{C}\right)$,

$\mathrm{T}$ max is maximum daily temperature $\left({ }^{\circ} \mathrm{C}\right)$,

$\mathrm{T}_{\min }$ is minimum daily temperature $\left({ }^{\circ} \mathrm{C}\right)$,

$\mathrm{Ra}$ is Solar radiation $\left(\mathrm{MJ} / \mathrm{m}^{2} / \mathrm{d}\right)$.

Determination of the mean daily temperature $\mathrm{T}_{\text {mean: }}$

$\mathrm{T}_{\max }=\underline{\text { sum of all the } \mathrm{T}_{\max } \text { for the month }}$ No of days of the month

$\mathrm{T}_{\min }=\underline{\text { sum of all the } \mathrm{T}_{\min } \text { for the month }}$ No of days of the month

$$
\mathrm{T}_{\text {mean }}=\frac{\mathrm{T}_{\max }+\mathrm{T}_{\min }}{2}
$$

\section{Actual Crop Evapotranspiration}

Crop Evapotranspiration $\left(\mathrm{ET}_{\mathrm{a}}\right)$ is an empirical estimate of the total amount of water required for a crop growing in an area under known climate conditions so that crop production is not limited by lack of water. The actual crop Evapotranspiration was calculated from measured soil moisture content data obtained using gypsum blocks as outlined by Michael (1979). The average daily actual Evapotranspiration expressed was calculated using Equation (2).

$E T_{a}=\sum_{i=1}^{n} \frac{M_{1 i}-M_{2 i}}{100} \times B d_{i} D_{i}$

Where:

$\mathrm{ET}_{\mathrm{a}}$ is actual crop evapotranspiration $\mathrm{mm} /$ day

$\mathrm{M}_{1}$ is the gravimetric moisture content $(\mathrm{g} / \mathrm{g})$ at the first sampling in the ith layer

$\mathrm{M}_{2}$ is the gravimetric moisture content $(\mathrm{g} / \mathrm{g})$ at the second sampling in the ith layer

$\mathrm{Di}$ is the depth of ith layer $(\mathrm{mm})$; $\mathrm{n}$ is the number of depth within the soil profile

Bdi is the specific gravity of the soil layer

The term consumptive use (CU) designates the losses due to Evapotranspiration $\left(\mathrm{ET}_{\mathrm{a}}\right)$, and water that is used by the plant for its metabolic processes. $\mathrm{CU}$ therefore exceeds $\mathrm{ET}_{\mathrm{a}}$ by the amount of water used for digestion, photosynthesis, transport of minerals, structural support and growth (James, 1988). Since this difference is usually less than 1\% (James, 1988), the term consumptive used is generally taken as equivalent to Actual Crop Evapotranspiration (ETa). ETa estimates serve as important data input in irrigation scheduling, in appraising the evapotranspiration performance of a field crop and in the computation of other accessory parameters including seasonal crop water use, water use efficiency as well as other relevant water use indices. This informs the need for careful determination of $\mathrm{ET}_{\mathrm{a}}$.

\section{Crop coefficient $\left(K_{c}\right)$}

The crop coefficient $\left(\mathrm{K}_{\mathrm{c}}\right)$ relates the actual rate at which a crop uses water (ET) to reference Evapotranspiration (ETo). Burman et al., (1983) defined $\mathrm{K}_{\mathrm{c}}$ as the ratio of ET occurring for a specific crop at a specific stage of growth to the potential ET at that time. Also, James, (1988) reported that crop coefficients for specific locations under particular growth conditions could simply be expressed as the dimensionless ratio of Actual Crop Evapotranspiration to Reference Crop or Potential Evapotranspiration. That is;

$$
K_{c}=\frac{E T_{a}}{E T_{o}}
$$

Where:

$\mathrm{K}_{\mathrm{c}}$ is crop coefficient

$\mathrm{ET}_{\mathrm{o}}$ is reference crop evapotranspiration ( $\mathrm{mm} /$ day)

$\mathrm{ET}_{\mathrm{a}}$ is actual crop evapotranspiration ( $\mathrm{mm} /$ day)

$\mathrm{K}_{\mathrm{c}}$ for field and vegetable crops generally increase gradually from an initial low value to a peak plateau and then declines as the plant progresses to its maturity stage (James,1988) . 
Crop coefficient for growth stage $\left({ }^{*} \mathrm{~K}_{\mathrm{c}}\right)$

Crop coefficient $\left({ }^{*} \mathrm{~K}_{\mathrm{c}}\right)$ values for each growth stages was determined through the use of equation (3a) \&(3b) respectively:

$* \mathrm{~K}_{\mathrm{c}}=\mathrm{a} * \mathrm{ET}_{\mathrm{o}}{ }^{\mathrm{b}}$

Where $* \mathrm{~K}_{\mathrm{c}}=$ crop coefficient for the duration of a growth stage

$$
\begin{aligned}
& \mathrm{a}=\text { coefficient } \\
& \mathrm{b}=\text { exponent }
\end{aligned}
$$

$* \mathrm{ET}_{\mathrm{o}}=$ average daily reference crop ET for a duration of a growth stage.

$\log \left({ }^{*} \mathrm{~K}_{\mathrm{c}}\right)=\log (\mathrm{a})+\mathrm{blog}\left({ }^{*} \mathrm{ET}_{\mathrm{o}}\right)$

By plotting the graph of $\log \left({ }^{*} \mathrm{~K}_{\mathrm{c}}\right)$ vs $\log \left({ }^{*} \mathrm{ET}_{\mathrm{o}}\right)$, the values of ' $a$ ' and ' $b$ ' were obtained and the values of crop coefficient $\left({ }^{*} \mathrm{~K}_{\mathrm{c}}\right)$ for each growth stage were determined.

\section{Statistical Analysis}

Data obtained were subjected to statistical analysis of variance and the significance among treatment means was evaluated with Duncan's Multiple Range Test to check significant differences between the treatments.

\section{RESULTS AND DISCUSSION \\ Soil Physical Properties}

The soil physical properties for sampled plots from the soil physical properties of plots $\mathrm{T} 1$ to $\mathrm{T} 7$ showed that there was not much variation within the selected farms in the study area as reported by Ahmed, et al., (2020). The soil of the experimental site is predominantly sandy loam. All the soils were found to be of a homogenous profile within the $0-600 \mathrm{~mm}$ depth.

The meteorological data for the period of the study was obtained from the Institute for Agricultural Research (IAR), located $60 \mathrm{~km}$ away from the experimental plots were used as input for the Hargreaves Equation to estimate monthly ETo as presented in Table 2 .

\begin{tabular}{|c|c|c|c|c|c|c|c|}
\hline Months & $\begin{array}{l}\text { Max. } \\
\text { Temp. } \\
\left({ }^{0} \mathrm{C}\right)\end{array}$ & $\begin{array}{l}\text { Min. } \\
\text { Temp. } \\
\left({ }^{0} \mathrm{C}\right)\end{array}$ & $\begin{array}{l}\text { Humidity } \\
(\%)\end{array}$ & $\begin{array}{l}\text { Wind } \\
\text { Speed } \\
(\mathrm{Km} / \mathrm{d})\end{array}$ & $\begin{array}{l}\text { Sunshine } \\
\text { (Hours) }\end{array}$ & $\begin{array}{l}\text { Solar Rad } \\
\left(\mathrm{MJ} / \mathrm{m}^{2} / \mathrm{d}\right)\end{array}$ & $\begin{array}{l}\mathrm{ETO}^{\mathrm{a}} \\
(\mathrm{mm} / \mathrm{d})\end{array}$ \\
\hline December & 30.7 & 14.0 & 39.0 & 199.0 & 9.3 & 20.1 & 5.43 \\
\hline January & 30.7 & 14.0 & 32.0 & 225.0 & 8.9 & 20.1 & 4.64 \\
\hline February & 32.6 & 15.8 & 29.0 & 225.0 & 9.4 & 22.2 & 5.34 \\
\hline March & 35.2 & 19.3 & 31.0 & 173.0 & 9.0 & 23.0 & 6.15 \\
\hline April & 35.7 & 21.6 & 53.0 & 173.0 & 8.0 & 21.9 & 6.30 \\
\hline
\end{tabular}

Table 2 Weather data for the 2008/ 2009 irrigation cropping Season

${ }^{a}$ average weekly ETo for 10 years (1999-2009) using Hargreaves equation

\section{Estimation of Weekly ET}

Using the Hargreaves equation an average of 10-year weather data was used to determine the reference Evapotranspiration $\left(\mathrm{ET}_{\mathrm{o}}\right)$ as presented in Table 3. 
Table 3: Reference Crop Evapotranspiration ( ET $_{0} \mathrm{~mm} /$ day ) from January-May

\begin{tabular}{|c|c|c|c|c|c|c|c|c|c|}
\hline January & $\mathrm{ET}_{\mathrm{o}}$ & February & $\mathrm{ET}_{\mathrm{o}}$ & March & $\mathrm{ET}_{\mathrm{o}}$ & April & $\mathrm{ET}_{\mathrm{o}}$ & May & $\mathrm{ET}_{\mathrm{o}}$ \\
\hline 1 & 4.5 & 1 & 4.8 & 1 & 5.6 & 1 & 6.4 & 1 & 6.2 \\
\hline 2 & 4.4 & 2 & 5.3 & 2 & 5.8 & 2 & 6.2 & 2 & 6.2 \\
\hline 3 & 4.2 & 3 & 5.1 & 3 & 6.0 & 3 & 6.5 & 3 & 6.3 \\
\hline 4 & 4.2 & 4 & 5.1 & 4 & 6.1 & 4 & 6.7 & 4 & 6.5 \\
\hline 5 & 4.3 & 5 & 5.0 & 5 & 6.1 & 5 & 6.9 & 5 & 6.5 \\
\hline 6 & 4.4 & 6 & 4.9 & 6 & 6.1 & 6 & 6.6 & 6 & 6.5 \\
\hline 7 & 4.4 & 7 & 5.1 & 7 & 6.2 & 7 & 6.8 & 7 & 6.6 \\
\hline 8 & 4.3 & 8 & 5.1 & 8 & 6.1 & 8 & 6.6 & 8 & 6.4 \\
\hline 9 & 4.5 & 9 & 5.0 & 9 & 6.2 & 9 & 6.3 & 9 & 6.3 \\
\hline 10 & 4.3 & 10 & 4.9 & 10 & 6.2 & 10 & 6.4 & 10 & 6.4 \\
\hline 11 & 4.3 & 11 & 5.1 & 11 & 6.3 & 11 & 6.4 & 11 & 6.2 \\
\hline 12 & 4.4 & 12 & 5.1 & 12 & 6.1 & 12 & 6.3 & 12 & 6.2 \\
\hline 13 & 4.6 & 13 & 5.3 & 13 & 6.0 & 13 & 6.4 & 13 & 6.4 \\
\hline 14 & 4.5 & 14 & 5.2 & 14 & 6.0 & 14 & 6.2 & 14 & 6.6 \\
\hline 15 & 4.6 & 15 & 5.3 & 15 & 6.2 & 15 & 6.2 & 15 & 6.3 \\
\hline 16 & 4.7 & 16 & 5.1 & 16 & 6.2 & 16 & 6.4 & 16 & 6.2 \\
\hline 17 & 4.8 & 17 & 5.3 & 17 & 6.0 & 17 & 6.4 & 17 & 6.1 \\
\hline 18 & 4.9 & 18 & 5.5 & 18 & 6.2 & 18 & 6.6 & 18 & 6.2 \\
\hline 19 & 4.9 & 19 & 5.6 & 19 & 6.3 & 19 & 6.3 & 19 & 6.2 \\
\hline 20 & 5.0 & 20 & 5.8 & 20 & 6.3 & 20 & 6.2 & 20 & 6.4 \\
\hline 21 & 4.8 & 21 & 5.9 & 21 & 6.4 & 21 & 6.1 & 21 & 6.4 \\
\hline 22 & 4.9 & 22 & 5.8 & 22 & 6.2 & 22 & 5.9 & 22 & 6.2 \\
\hline 23 & 5.0 & 23 & 5.7 & 23 & 6.3 & 23 & 6.0 & 23 & 6.1 \\
\hline 24 & 5.1 & 24 & 5.8 & 24 & 6.0 & 24 & 5.9 & 24 & 6.3 \\
\hline 25 & 5.1 & 25 & 5.6 & 25 & 6.0 & 25 & 5.9 & 25 & 6.2 \\
\hline 26 & 5.1 & 26 & 5.7 & 26 & 6.0 & 26 & 6.1 & 26 & 6.1 \\
\hline 27 & 4.7 & 27 & 5.7 & 27 & 6.0 & 27 & 5.6 & 27 & 6.3 \\
\hline 28 & 4.9 & 28 & 5.7 & 28 & 6.5 & 28 & 6.0 & 28 & 6.2 \\
\hline 29 & 4.5 & & & 29 & 6.4 & 29 & 6.4 & 29 & 6.1 \\
\hline 30 & 4.6 & & & 30 & 6.4 & 30 & 6.2 & 30 & 6.2 \\
\hline 31 & 4.9 & & & 31 & 6.4 & & & 31 & 6.3 \\
\hline
\end{tabular}

a average weekly ETo for 10 years (1999-2009) using Hargreaves equation.

Crop Coefficientfor various growth stages

Figures 1(a-d) show the plot of $\log \left({ }^{*} \mathrm{~K}_{\mathrm{c}}\right)$ vs $\log \left({ }^{*} \mathrm{ET}_{\mathrm{o}}\right)$ for Plot $\mathrm{T} 1$ for the initial, crop development, mid-season and late growth stages respectively. The values of $* K_{c}$ obtained are presented in Table 4. 


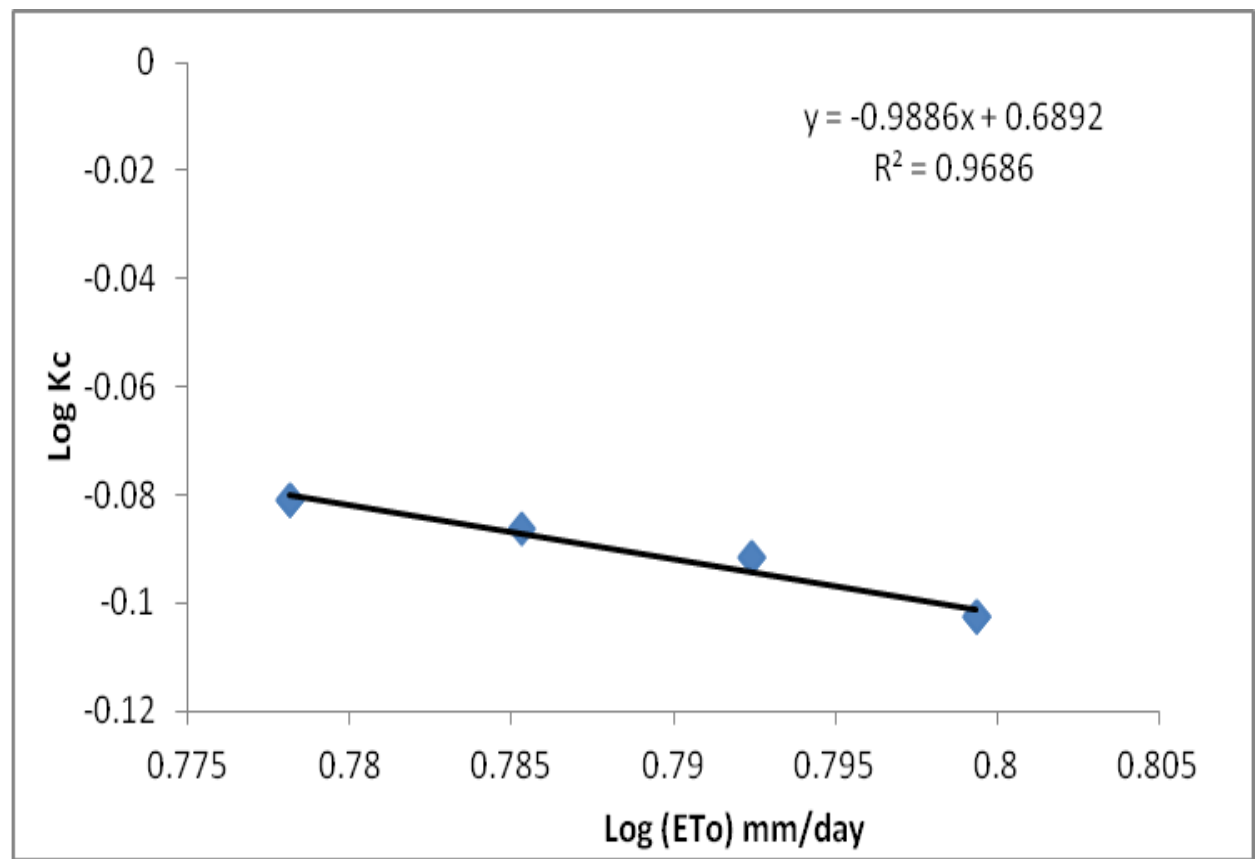

Fig. 1a: Graph of $\log \left({ }^{*} \mathrm{~K}_{\mathrm{c}}\right) \mathrm{vs} \log \left({ }^{*} \mathrm{ET} \mathrm{T}_{\mathrm{o}}\right)(\mathrm{mm} /$ day) for Plot T1 (initial stage)

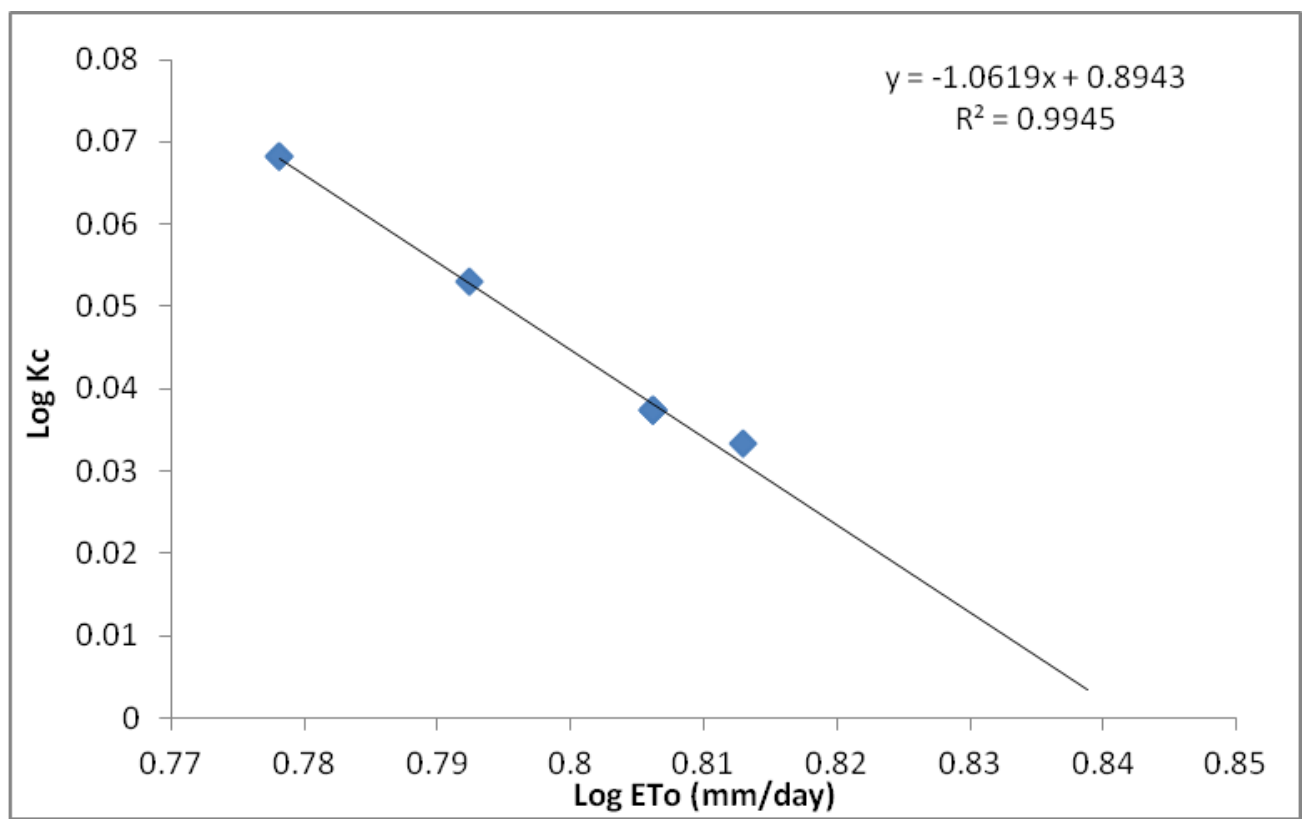

Fig.1b:Graph of $\log \left(* \mathrm{~K}_{\mathrm{c}}\right) \mathrm{vs} \log \left(* \mathrm{ET}_{\mathrm{o}}\right)(\mathrm{mm} /$ day $\left.)\right)$ for Plot T1 (Development stage) 


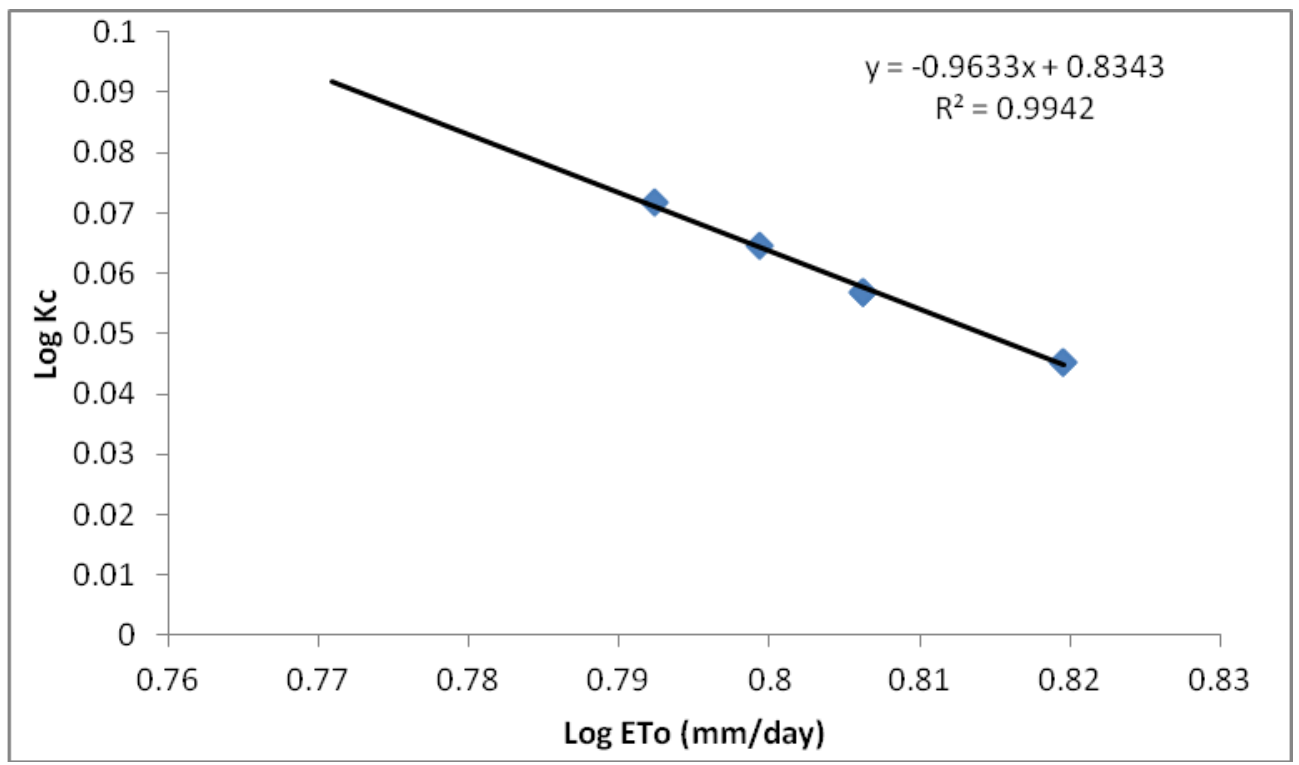

Fig.1c: Graph of $\log \left({ }^{*} \mathrm{~K}_{\mathrm{c}}\right)$ vs $\log \left({ }^{*} \mathrm{ET}_{\mathrm{o}}\right)(\mathrm{mm} /$ day) for Plot T1 (Mid season stage)

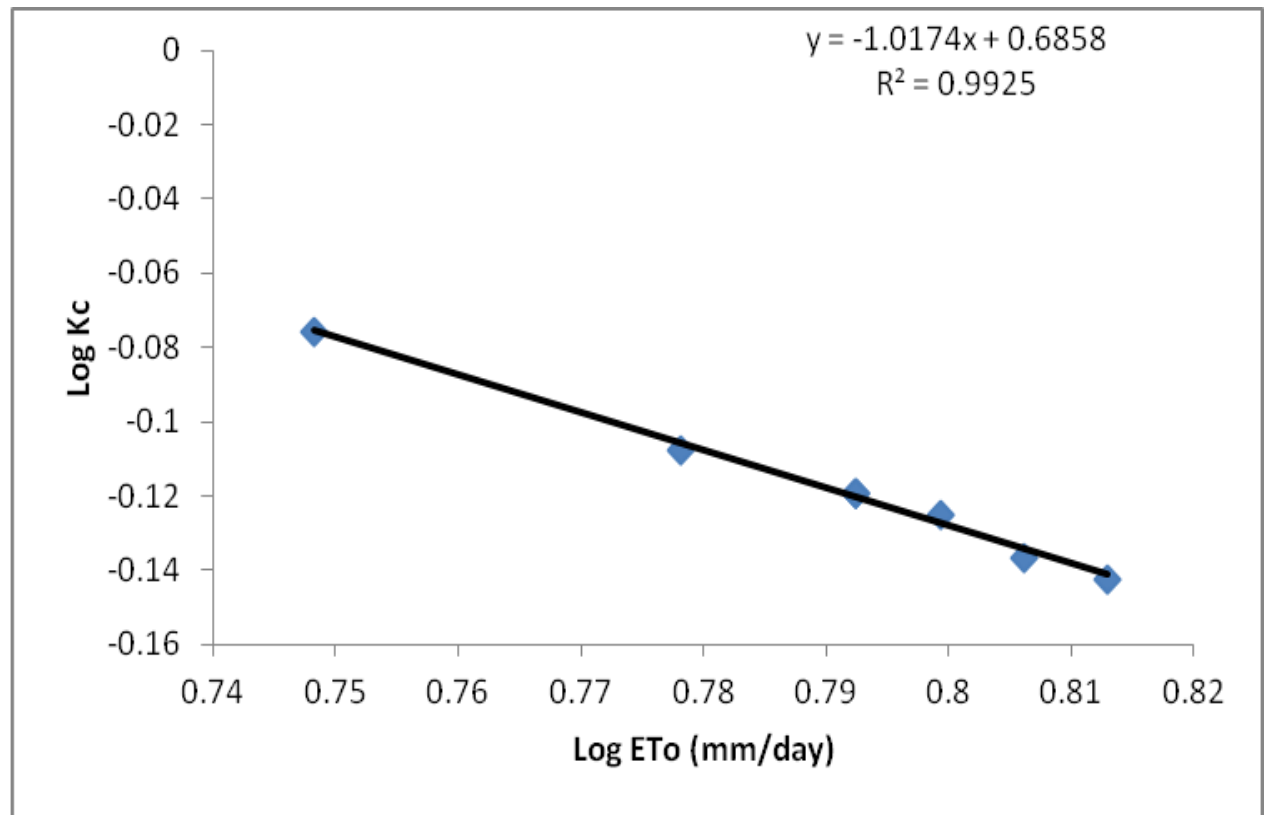

Fig.1d Graph of $\log \left({ }^{*} \mathrm{~K}_{\mathrm{c}}\right)$ vs $\log \left({ }^{*} \mathrm{ET}_{\mathrm{o}}\right)(\mathrm{mm} /$ day) for Plot T1 (Late stage)

Crop coefficient $\left(\mathrm{K}_{\mathrm{c}}\right)$ estimates is particularly important for this stage because mid-season Kc refers to the peak $\mathrm{K}_{\mathrm{c}}$ values and relies on the period of growing season that is usually the most relevant for irrigation and the most sensitive to water stress, thus the period where accurate scheduling should be applied.

Table 4 shows the computed ${ }^{*} \mathrm{~K}_{\mathrm{c}}$ values for different growth stage for the tomato crop grown in the Pampaida Millennium Village, it was found to be between 0.77-1.15. This was similar to $\mathrm{K}_{\mathrm{c}}$ values reported by Allen et al., (1998) as initial stage (0.4 $0.5)$, crop development stage (0.7-0.8), the mid- season stage (1.05-1.25), the late-season stage (0.8-0.9). 
Table 4 Computed $K_{c}$, at various growth stages for Pampaida MV

\begin{tabular}{lcc}
\hline Growth stage & $* \mathrm{~K}_{\mathrm{c}}$ equation & $* \mathrm{~K}_{\mathrm{c}}$ values \\
\hline Initial & $* \mathrm{~K}_{\mathrm{c}}=4.9 * \mathrm{ET}_{\mathrm{o}}{ }^{-0.9886}$ & 0.80 \\
Crop development & $* \mathrm{~K}_{\mathrm{c}}=7.8 * \mathrm{ET}_{\mathrm{o}}^{-1.0619}$ & 1.09 \\
Mid-season & $* \mathrm{~K}_{\mathrm{c}}=6.8 * \mathrm{ET}_{\mathrm{o}}{ }^{-0.9633}$ & 1.15 \\
Late & $* \mathrm{~K}_{\mathrm{c}}=4.9 * \mathrm{ET}_{\mathrm{o}}{ }^{-1.0174}$ & 0.77 \\
\hline
\end{tabular}

It was also observed that the mid-season stage had the highest $\mathrm{K}_{\mathrm{c}}$ values of 1.15. According to Doorenbos and Kassam, (1979) the $K_{c}$ value for this stage is usually the highest as compared to the other growth stages.

Table 5 shows that the computed seasonal water requirement is estimated to be $386 \mathrm{~mm}$. According to FAO, (1998) total water requirements after transplanting, of a tomato crop grown in the field for 90 to 120 days, are 400 to $600 \mathrm{~mm}$ respectively, depending on the climate. However, Silva et al., (1996), reported a seasonal water requirement range of 300 to $400 \mathrm{~mm}$ for tomato. 
Table 5 Crop water requirement per growth stage and the computed irrigation schedule for the study area

\begin{tabular}{|c|c|c|c|c|c|c|c|}
\hline $\begin{array}{c}\text { Growth stage } \\
\text { (No of days) } \\
{ }^{*} \mathrm{~K}_{\mathrm{c}}\end{array}$ & $\begin{array}{c}{ }^{*} \mathrm{ET}_{\mathrm{o}} \\
\text { (average } \\
\mathrm{mm} / \text { day) }\end{array}$ & $\begin{array}{c}* \mathrm{ET}_{\mathrm{a}} \\
\text { (average } \\
\mathrm{mm} / \text { day) }\end{array}$ & $\begin{array}{l}\text { Irrigation } \\
\text { Interval } \\
\text { (days) }\end{array}$ & $\begin{array}{l}\text { Computed crop } \\
\quad \text { water } \\
\text { requirement / } \\
\text { irrigation }(\mathrm{mm})\end{array}$ & $\begin{array}{l}\text { No. of } \\
\text { irrigation/g } \\
\text { rowth stage }\end{array}$ & $\begin{array}{c}\text { Computed crop } \\
\text { water requirement } \\
\text { /growth stage }(\mathrm{mm})\end{array}$ & $\begin{array}{c}\text { **Time of irrigation per } \\
\text { ha } \\
(\mathrm{hrs})\end{array}$ \\
\hline $\begin{array}{c}\text { Initial stage (15) } \\
\left(* K_{c}=0.81\right)\end{array}$ & 6.2 & 5 & 4 & 20 & 4 & 80 & 12.6 \\
\hline $\begin{array}{c}\text { Development stage } \\
(18) \\
\left(* K_{c}=1.09\right)\end{array}$ & 6.4 & 7 & 4 & 28 & 4 & 112 & 17.6 \\
\hline $\begin{array}{l}\text { Mid season stage }(18) \\
\qquad\left(* \mathrm{~K}_{\mathrm{c}}=1.15\right)\end{array}$ & 6.3 & 7.3 & 4 & 29.2 & 4 & 117 & 18.3 \\
\hline \multirow[t]{2}{*}{$\begin{array}{l}\text { Late Stage (10) } \\
\left(* \mathrm{~K}_{\mathrm{c}}=0.77\right)\end{array}$} & 6.2 & 4.8 & 4 & 19.2 & 4 & 77 & 11.10 \\
\hline & & & & & Total & 386 & \\
\hline
\end{tabular}


The average of 98 days was required to grow tomato from seeding to harvesting Stage which was observed to be shorter than that suggested by FAO (100-135 days) for the tomato grown in tropical climate. This can be explained by shorter season varieties that were widely adopted by the farmers in the study area. According to Doorenbos and Pruitt, (1977), the range takes into account crop characteristics, time of planting and general climatic conditions. Table 5 also shows the computed crop water requirement per irrigation and for each of the growth stages to be $(20 \mathrm{~mm} ; 80 \mathrm{~mm})$ at the initial stage, $(28 \mathrm{~mm} ; 112 \mathrm{~mm})$ at the crop development stage, $(29 \mathrm{~mm} ; 117 \mathrm{~mm})$ at the mid-season stage and $(19 \mathrm{~mm} ; 77$ $\mathrm{mm})$ at late stage.

The farmers, in their traditional practice, apply water to their crops based on individual discretion. However, According to Mofoke et al., (2002), for most small holder farmer's water application is done at intervals based on the farmers' initiative, not necessarily backed by scientific principle.

\section{CONCLUSION}

Crop coefficient model equation $\left({ }^{*} \mathrm{~K}_{\mathrm{c}}\right)$ for different growth stages, were determined for Pampaida Millennium Village to be, initial $\left({ }^{*} \mathrm{~K}_{\mathrm{c}}=4.9 * \mathrm{ET}_{\mathrm{o}}{ }^{-0.9886}\right)$, development stage $\left(* \mathrm{~K}_{\mathrm{c}}=7.8 * \mathrm{ET}_{\mathrm{o}}{ }^{-1.0619)}\right.$, mid-season stage $\left(* \mathrm{~K}_{\mathrm{c}}=6.8 * \mathrm{ET}_{\mathrm{o}}{ }^{-0.9633}\right)$ and late stage $\left({ }^{*} \mathrm{~K}_{\mathrm{c}}=\right.$ $\left.4.9 * \mathrm{ET}_{\mathrm{o}}{ }^{-1.0174}\right)$. Furthermore, based on the $* \mathrm{~K}_{\mathrm{c}}$ values obtained, the computed crop water requirement obtained were, initial stage $\left({ }^{*} \mathrm{~K}_{\mathrm{c}}=0.81 ; 20 \mathrm{~mm} /\right.$ irrigation $)$, development stage $\left({ }^{*} \mathrm{~K}_{\mathrm{c}}=1.09 ; 28\right.$ $\mathrm{mm} /$ irrigation $)$, mid-season $\left({ }^{*} \mathrm{~K}_{\mathrm{c}}=1.15 ; 29 \mathrm{~mm} /\right.$ irrigation and Late stage $\left({ }^{*} \mathrm{~K}_{\mathrm{c}}=0.77 ; 19 \mathrm{~mm} /\right.$ irrigation $)$ and are recommended for the study area for irrigation design and scheduling.

\section{REFERENCES}

Ahmed, A. (2016) Assessment of Tomato Farmers' Irrigation Practice in Pampaida Millennium Village, Ikara Local Government Area, Kaduna State, Nigeria. Unpublished Msc Thesis, Department of Agricultural Engineering, Faculty of Engineering, Ahmadu Bello University, Zaria Nigeria.

Ahmed A., Oyebode, M.A., Igbadun H. E, and Oiganji, E. (2020) Assessment of Tomato Farmers' Irrigation Practice in Pampaida Millennium Village, Ikara Local Government Area, Kaduna State, Nigeria. FUDMA Journal of Sciences (FJS) Vol. 4 No. 2, June, 2020,pp 499-599

Ali, M. H. (2010). Fundamentals of Irrigation and on Farm Water Management. Springer Science and Business Media, LLC. London.

Allen, R.G., L.S. Pereira, D. Raes, and M. Smith. (1998). Crop Evapotranspiration: Guideline for Computing crop Water Requirements.FAO Irrigation and Drainage paper No 56,300pp

Burman,R.D., R. H. Cuenca and A. Weiss. 1983. Techniques for estimating irrigation Water Requirements. In: Advances in irrigation Vol. 2 (D. Hillel, ed.) Academic Press, New York, N.Y. : 336-391
Doorenbos, J and W.O. Pruitt. 1977. Guidelines for predicting crop water requirements. Irrigation and Drainage paper 24, FAO, Rome

Doorenbos, J. and A.H. Kassam (1979); Yield response to water.Irri. Drain. Paper33.FAO,Rome, Italy FAO, 1998. Crop evapotranspiration - guidelines for computing crop water requirements. In:Allen, R.G.,Pereira, L.S., Raes, D., Smith, M. (Eds.), Irrigation and Drainage Paper 56. FAO, Rome, Italy, p. 300.

Ho, L. C. (1996) Tomato In: E. Zemaski, and A. A,Schaffer (Eds.). Photoassimilate distribution in plant and crops: Source-Sinks relationship. NY, USA: Marcel Dekker, pp709-728. Hort.Science 31, 926-929.

Igbadun, H.E and Ezekiel Oiganji (2012).Crop coefficients and yield response factors for onion (Allium Cepa. L) under deficit irrigation and mulch practices in Samaru, Nigeria African Journal of Agricultural Research Vol. 7(36), pp. 5137-5152

James,L.G. (1988).Principles of farm Irrigation System Design.John wiley and Sons, New York,N.Y.

Michael, A.M (1978). Irrigation, theory and practice. Vani Educational Books, India.

Mofoke A.L.E, Ahmed A, Mudiare OJ (2002). Evaluation of Fadama Irrigation Efficiencies around Samaru, Zaria, Nigeria. J. Agri. Environ., 3(2): 319-329

Loveday, J (1974) Method for analysis of irrigation soils. Tech. Communication,no.45 of Commonwealth Bureau of Soils. Australia

Opiyo, A. A. and Ying, T. J. (2005) The effect of 1methylcycopropene treatment on the shelf-life and quality of cherry tomato (Lycopersicn esculentum var. cerasiforme) fruit. International Journal Food Sci Techn 40; 665-673.

Sanchez P.A, Palm C.A, Sachs J.D., Denning G.L., Flor R., Zamba C.(2009). "The African Millennium Villages." Proceedings of the National Academy of Sciences 104.

Schwab, G. O., Fangmeier, D. D., Elliot, W. J. and Frevert, R. K. (1993) Soil and Water Conservation Engineering, (4th Ed.). NY, USA: Wiley and Sons Inc.

Silva, W. L. C. and Maroucelli W. A. (1996) Evaluation of Irrigation Scheduling Techniques for Processing Tomato in Brazil. In: International Conference on Evapotranspiration and Irrigation scheduling, Proceedings, 522-526. St Joseph, MI: ASA

World Bank, (2011). Water Resources Management. Retrieved, 10th December, 2015 from

http//water.worldbank.org/water/topics/agricultural water management

C2020 This is an Open Access article distributed under the terms of the Creative Commons Attribution 4.0 International license viewed via https://creativecommons.org/licenses/by/4.0/ which permits unrestricted use, distribution, and reproduction in any medium, provided the original work is cited appropriately. 